\title{
PROPOSAL OF AN INDICATOR TO MEASURE THE PROFESSIONALIZATION OF ELECTION CAMPAIGNS: THE CASE OF COLOMBIA
}

\author{
Propuesta de un indicador para medir la \\ profesionalización de las campañas electorales: \\ el caso de Colombia
}

Néstor-Julián Restrepo-Echavarría, Raquel Rodríguez-Díaz and Antón R. Castromil

Nota: Este artículo se puede leer en español en:

http://www.elprofesionaldelainformacion.com/contenidos/2018/mar/07_esp.pdf

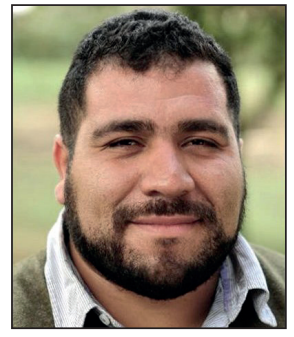

Néstor-Julián Restrepo-Echavarría is a doctor in Politics, Communication and Culture from the Universidad Complutense de Madrid and has a masters degree in Latin American Studies with Politics from the Universidad de Salamanca. As a political expert with a degree in Social Communication, he is a lecturer in the Communication Faculty of the Universidad de Medellín. His main areas of research are political communication, political parties, social movements, and geopolitics. https://orcid.org/0000-0002-2881-1249

Universidad de Medellín; Facultad de Comunicación Carrera 87 - N 30-65, Medellín, Colombia njrestrepo@udem.edu.co

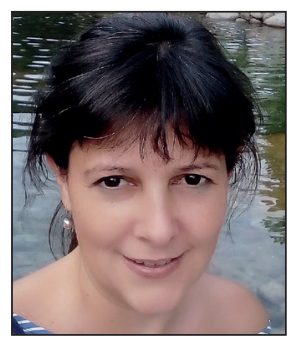

Raquel Rodríguez-Díaz has a degree and is a doctor in Information Sciences from the Universidad Complutense de Madrid and is a university lecturer in the Faculty of Communication Sciences at the Universidad Rey Juan Carlos. She carries out research on the effect of the media on communication and health, political communication, the theory of framing and agenda-setting, using the issues of public opinion in Spain. She has two 6-year tenures in research and has taken part in both publicly- and privately-funded projects at both national and international levels. She has been a member of the research group Agenda y voto ("Agenda and vote") in the Faculty of Communication Sciences at the Universidad Complutense de Madrid.

https://orcid.org/0000-0002-8097-6585

Universidad Rey Juan Carlos; Facultad de Ciencias de la Comunicación Camino del Molino, s/n. 28943 Fuenlabrada (Madrid), Spain raquel.rodriguez@urjc.es

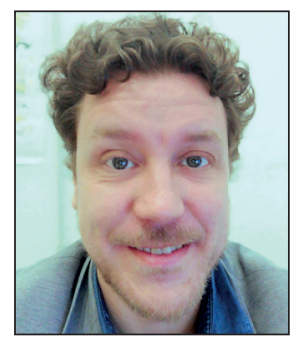

Antón R. Castromil, is a doctor in Communication from the Universidad Complutense de Madrid (UCM) and has studied Communication and Journalism at the Universidad Pontificia de Salamanca, Political Sciences at the UCM and Analysis of Survey Data at the University of Essex (United Kingdom). He is an associate lecturer in the Department of Sociology VI and co-ordinator of the Masters in Advanced Studies in Political Communication at the UCM. He has been a visiting researcher at the Universidad de Cabo Verde, the Universidade Técnica de Lisboa (Portugal) and the University of Hull (UK). He has been a researcher on various projects financed by the Spanish National R\&D Plan since 2008. His research areas cover political communication, public opinion, and the effects of the media on democratic regimes. His work in communication theory is aimed at demonstrating the power to explain of new and traditional media in the process of public opinion, with a strong emphasis on survey data, content analysis and the methodology of focus groups. https://orcid.org/0000-0001-9461-6647

Universidad Complutense de Madrid; Facultad de Ciencias de la Información Av. Complutense, s/n. 28040 Madrid, España arcastromil@ccinf.ucm.es 


\section{Abstract}

An indicator is proposed that measures the degree of professionalization of presidential campaigns in political systems where there is high personalization and low institutionalization of political parties. The professionalization of Colombia's 2014 presidential campaign is measured: describing both the organizational dimension and internal structure of the campaign, and the communication strategy used to persuade the voters. Dimensions and categories are established that show the development and evolution of the techniques used in the presidential campaign.

\section{Keywords}

Professionalization; Electoral campaigns; Professionalization level; Political communication; Indicators; Colombia.

\section{Resumen}

Se propone un indicador que permite medir el grado de profesionalización de las campañas presidenciales en sistemas políticos en los que hay una alta personalización y una baja institucionalización de los partidos políticos. Se mide la profesionalización de la campaña presidencial de Colombia en el año 2014, describiendo tanto la dimensión organizativa, explicando la estructura interna de una campaña, y la dimensión comunicativa, donde se elabora la estrategia de comunicación para persuadir a los electores. Para estas dos dimensiones se establecen unas categorías que muestran las técnicas de una campaña presidencial.

\section{Palabras clave}

Profesionalización; Campañas electorales; Nivel de profesionalización; Comunicación política; Indicadores; Colombia.

Restrepo-Echavarría, Néstor-Julián; Rodríguez-Díaz, Raquel; Castromil, Antón R. (2018). "Proposal of an indicator to measure the professionalization of election campaigns: The case of Colombia". El profesional de la información, v. 27, n. 2, pp. 289-299.

https://doi.org/10.3145/epi.2018.mar.07

\section{Introduction: Definition and scope}

The rise of the concept of professionalization of campaigns can be witnessed in all political changes and transformations in the twentieth century, mainly as a result of the arrival of new information technologies and their influence on debate, political communication and the different strategies for achieving power (Castells, 2009). Crespo, Garrido \& Riorda (2008) point out that the appearance of this phenomenon in politics may be attributed to the following factors:

- the decline of political parties and their role when it comes to choosing candidates;

- the upsurge of a complex system of communication media, centered mainly on television but with a rising diversity of flexible media which are inter-connected electronically;

- claim that the candidates, the political parties and the media have all become professional following the tendencies, trends and guidelines which have come from North America with the incursion of political marketing on the political arena (Plasser; Plasser, 2002; Swanson; Mancini, 1996; Norris, 2001).

Swanson \& Mancini (1996), Mancini (1995) \& Blumler (1999) use the term "media-centered democracy" and believe that the correct term should be "modern publicity process".

In addition, they establish that these tendencies in the process of professionalization of campaigns are a consequence of the emergence of a series of common factors which would appear to play a key role and which appear both in the modernization which both the media and also poli- tics and government have undergone (Swanson; Mancini, 1996).

In that sense, it could be said that a professional campaign is one which uses tactics and strategies with a high-profile, intensive use of mass media, as well as the most recent technological innovations to reach voters (media-intensive). These innovations are guided by sophisticated market research and public opinion methods (surveys, discussion groups, data bases, research into the opposition, etc.) (poII-driven) and planned by professional consultants, who are experts in political marketing and management of the media (consultant-driven). In a professionalized campaign, modern techniques have taken over from (or, at least considerably displaced), the more traditional campaign practices, based on direct contact with voters and the extensive use of party volunteers (Farrel, 1996).

Orejuela (2006) states that professionalization refers to the process of transformation, influence and similarity which appear in current electoral campaigns. In addition, he says that the term "professionalization" comes from modernization because it incorporates the election media and, as such, it is necessary to bring in experts in this field who can manage campaign strategies and compose messages.

In the same way, Holtz-Bacha (2002) suggests that the term has appeared as a consequence of social changes - the new generation of citizens do not have clear political identities and are more volatile.

Faced with this panorama, winning votes has become a noholds-barred battle which must be led by professional stra- 
tegists. Holtz-Bacha (2002) develops their hypothesis based on the theory of Swanson \& Mancini (1996), explaining that professionalization is a consequence of the modernization of societies and, at the same time, it is the trigger for other media and political elements.

\section{Person-centered political systems in Latin America and Colombia}

One particular case study for analyzing the phenomenon of professionalization, are the electoral campaigns in Latin-America which, thanks to their geographical and cultural proximity to the USA have experienced the Americanization of the techniques and processes in professional electoral campaigns.

The traditional style of Latin American campaigns was founded on the mass gatherings of followers, leading to a fiery speech and the frenetic applause of the faithful. Such an event, according to Plasser \& Plasser (2002) has lost importance in recent years and electoral campaigns have been carried out in television studios.

The professionalization of campaigns is a consequence of the modernization of societies and, in turn, is the cause of other media and political elements

On the other hand, the presidentialist element of the political system in Latin America has favored a person-focused culture in politics, with the campaign tending to center on the candidate to the detriment of the party and political agendas (Martínez-Pandiani, 2006, Restrepo-Echavarría, 2015). In fact, those campaigns are free-access - with few exceptions, such as Brazil and Chile - and advertising space on the media can be purchased to spread political propaganda, with the result that the cost of campaigns in that region has increased exponentially. Consequently, politics in Latin America has become susceptible to corruption, leading to voters becoming pessimistic, uninterested and indifferent (Plasser; Plasser, 2002).

Another fundamental feature of professionalization in campaigns in Latin America is the proliferation of external advisers who replace professional militants. Initially, they were US advisers who intervened in campaigns in Latin America but then left behind them a large school which produced a proliferation of political marketing gurus in the region who offered their services and implemented their techniques throughout the continent. In addition, there was an abundance of their writings in the shape of campaign manuals on offer in bookshops and at regional political communication events (Restrepo-Echavarría, 2017).

Another interesting case for studying the phenomenon of professionalization is that of the presidential elections in Colombia. Beginning with the change of the political constitution in 1991, the modernization of electoral campaigns at both a national and regional level began to be apparent. All that does not set aside the electoral traditions which belong to the Colombian culture - a significant culture, since, of all the countries of Latin America, it is the one without a long period of military dictatorship and was characterized by the continuity of electoral processes during the whole of the twentieth century.

The Colombian presidential elections moved gradually from the streets and squares to television debates, from political rallies to virtual forums, chatrooms and social networks in which national security and control are decisive elements when it comes to voting, ahead of other topics such as unemployment, corruption and the economy.

In Colombia, since 1990, the crisis in institutions and parties caused by corruption, the armed conflict, lack of legitimacy of the institutions of the state and the stagnation of traditional political parties has led to the passing of the political Constitution of 1991, which modified the design of institutions in the following terms:

- in the party system, it went from a two-party system to a multi-party one, in which the whole population had a political representation;

-in the electoral system, rules came into place which would allow a second round for the presidential election, recognizing the authority of the winner;

- changes were introduced in the funding of campaigns, with the system of mixed funding coming into effect;

- regional campaigns were more important after the election of mayors and governors and, finally, the electoral card was created on which the image of the candidate is more prominent than the party logo (Restrepo-Echavarría, 2017).

For Becassino (2008), all that has been mentioned has led to an increase in the electoral campaigns in Colombia taking advantage of the culture of consumption and with an emphasis on the agenda, speech and image, using short-term public feelings without caring about building lasting relationships with voters.

\section{Methodology}

In order to be able to establish the level of professionalization in campaigns, the suggested methodology has two dimensions:

- the organizational dimension; and

- the communicational dimension.

In each of these, six categories are drawn up with their respective indices. At the same time, a simplified, 3-tier measuring scheme has been set out to measure the frequency of use in the campaign, with which to add up the indices and obtain the final result, or Index. Greater detail regarding methodology is given in the following sections.

\subsection{Organizational dimension}

This dimension deals with the aspects related to the internal structure of the electoral campaign, which is understood as an electoral company with an organization and functional areas which are strategic, tactical and technical. The organizational dimension involves understanding the distinctive factors which describe the structures of power and communication flows with their interactions and transactions and lead to either the crystallization or the failure of the institutional project (Múnera; Sánchez, 2003, p. 187). 
Bartoli (1992) as quoted in Múnera \& Sánchez (2003) defines the factors which make up and differentiate any given organization as:

- its purpose;

- the distribution of roles and the tasks to be undertaken by all group members;

- the division of authority and formal power;

- the indeterminate duration (permanent mission) or clearly stated duration, depending on a specific objective;

- a system of communication and co-ordination; and, finally

- the assessment criteria and gathering of results.

Mintzberg (1979) contributes to the conceptualization of the organization, explaining what the basic elements are. In this way, the author indicates that the top of the organization brings together the directive and decision-making powers which define the mission, direction and strategies of the company. The hierarchical line marks the top and the base of the organization and includes the center of operations where the good/service is produced - this is also the raison d'être of the company.

Within this structure, logistical support is that which helps the entity to function whereas the techno structure becomes the analysis group made up of experts who study the areas of improvement. Basing their theory on the abovementioned, Múnera-Uribe \& Sánchez-Zuloaga (2003) conceive the organization as a whole which has a structure and elements which allow it to develop and reach goals, at the same time making it possible for the members of the organization, who are responsible for its development, to interact. Using the basis of those concepts which have been described, the organizational dimension of the presidential campaigns in Colombia was structured, taking into account three categories of analysis: strategy, tactics and technique - each one with its own particular analysis indicators.

\subsection{Communicational dimension}

With the aim of achieving greater efficiency in the campaigns, political marketing professionals rely on certain communication resources as a way of reaching the voter who identifies less and less with parties or social groupings. Consequently, the messages in campaigns tend towards the following characteristics (Neto, 2007, p. 199):

- the emphasis is on image: this converts the politician into the exact personification of voter expectations;

- superficiality, adapted to the feelings of a citizen who pays little attention to deep discussions;

- symbolic approach with general intent;

- sophisticated visual resources.

That all means that communication must be a corporate function; in other words, a duty of all and each of the members of the campaign team. In effect, the dimension of communication must be considered from a simple question of ontological coherence: if human communication is carried out using messages and acts, nobody in the organization can be exempt from these types of actions.

Within the process of communication, we can see:

- the use of speeches and their emotional effect;

- the communication processes required for the speech to be effective in the emotions of the electorate; and

- the technical means or necessary tools for carrying out the communication process.

Table 1. Organizational dimension of presidential elections in Colombia

\begin{tabular}{|c|c|}
\hline Category & Indicator \\
\hline \multirow{6}{*}{ Strategy } & $\begin{array}{l}\text { Leading the campaigns: centralized vs. de-centralized (Norris, 2004; Plasser; Plasser, 2002; Freidenberg, 2010; Gibson; Röm- } \\
\text { mele, 2001; Gibson; Römmele, 2009; Díaz, 2012; Neto, 2007) }\end{array}$ \\
\hline & $\begin{array}{l}\text { Presence of external consultants in the areas of management (Norris, 2004; Plasser; Plasser, 2002; Freidenberg, 2010; Gibson; } \\
\text { Römmele, 2001; 2009; Díaz, 2012; Neto, 2007) }\end{array}$ \\
\hline & Sources of autonomous funding, with fund-raising techniques which are outside the main structure of parties. \\
\hline & $\begin{array}{l}\text { The use of social research to follow up on the perceptions and reactions of the voters (managing the public agenda and political } \\
\text { situation) (Norris, 2004; Plasser; Plasser, 2002; Freidenberg, 2010; Gibson; Römmele, 2001; 2009; Díaz, 2012; Neto, 2007) }\end{array}$ \\
\hline & $\begin{array}{l}\text { Permanent campaigning. Breaking with the rigid, tight time framework of campaign communication (Maarek, 2009; Swanson; } \\
\text { Mancini, 1996; Rospir, 1999; Kavanagh, 2004; Plasser; Plasser, 2002) }\end{array}$ \\
\hline & Professional management of campaigns (Restrepo-Echavarría, 2017) \\
\hline \multirow{5}{*}{ Tactics } & $\begin{array}{l}\text { Sytematization of databanks (Norris, 2004; Plasser; Plasser, 2002; Freidenberg, 2010; Gibson; Römmele, 2001; 2009; Díaz, } \\
\text { 2012; Neto, 2007) }\end{array}$ \\
\hline & The professionalization of the campaign group -a multi- and inter-disciplinary work team (Restrepo-Echavarría, 2017) \\
\hline & Paid militancy in the campaign. (Restrepo-Echavarría, 2017) \\
\hline & $\begin{array}{l}\text { Person-centeredness of the campaign, focusing on the candidate and moving away form programs and ideological leanings of } \\
\text { the party (Person focus in politics- the outsider) (Norris, 2004; Plasser; Plasser, 2002; Freidenberg, 2010; Gibson; Römmele, } \\
\text { 2001; 2009; Díaz, 2012; Neto, 2007) }\end{array}$ \\
\hline & Conventions and inter-party alliances. Support \\
\hline \multirow{2}{*}{ Techniques } & $\begin{array}{l}\text { Electoral monitoring: The use of polls, surveys and focus groups (Norris, 2004; Plasser; Plasser, 2002; Freidenberg, 2010; Gib- } \\
\text { son; Römmele, 2001; 2009; Díaz, 2012; Neto, 2007) }\end{array}$ \\
\hline & $\begin{array}{l}\text { Media training and team training (Norris, 2004; Plasser; Plasser, 2002; Freidenberg, 2010; Gibson; Römmele, 2001; 2009; Díaz, } \\
\text { 2012; Neto, 2007; Mancini, 1995) }\end{array}$ \\
\hline
\end{tabular}

Source: Work of the research team based on the quoted authors 
Table 2. The communicative dimension of presidential campaigns in Colombia

\begin{tabular}{|c|c|}
\hline Category & Indicator \\
\hline \multirow{5}{*}{ Discourse } & Personalized messages (Martínez-Pandiani, 2006; Plasser; Plasser, 2002) \\
\hline & The symbolic use of references (Neto, 2007; Mazzoleni, 2010) \\
\hline & The segmentation of messages (Izurieta; Arteton; Perina, 2003) \\
\hline & The use of emotions in electoral messages (Restrepo-Echavarría, 2015) \\
\hline & New means of political discourse (Restrepo-Echavarría, 2017) \\
\hline \multirow{4}{*}{$\begin{array}{l}\text { Communication } \\
\text { processes }\end{array}$} & The construction of the image and positioning of the candidate (Restrepo-Echavarría, 2017) \\
\hline & Storytelling (Restrepo-Echavarría, 2017) \\
\hline & Participation in TV debates and social forums \\
\hline & $\begin{array}{l}\text { Use of negative propaganda (Norris, 2004; Plasser; Plasser, 2002; Freidenberg, 2010; Gibson; Römmele, 2001; Gibson; } \\
\text { Römmele, 2009; Díaz, 2012; Neto, 2007; Ramos-Meneghetti, 2003; Mancini, 1995; Maarek, 2009; Swanson; Mancini, 1996; } \\
\text { Rospir, 1999; Kavanagh, 2004) }\end{array}$ \\
\hline \multirow{5}{*}{ Technical means } & $\begin{array}{l}\text { Advertising inserts in mass media: Public and private radio and television (Norris, 2004; Plasser; Plasser, 2002; Freidenberg, } \\
\text { 2010; Gibson; Römmele, 2001; Gibson; Römmele, 2009; Díaz, 2012; Neto, 2007; Ramos-Meneghetti, 2003; Mancini, 1995; } \\
\text { Maarek, 2009; Swanson; Mancini, 1996; Rospir, 1999; Kavanagh, 2004). }\end{array}$ \\
\hline & Use of Internet (Cotarelo, 2010) \\
\hline & $\begin{array}{l}\text { The use of printed material for eternal use in electoral campaigns: Non-party press, advertising material, billboards, posters, } \\
\text { flyers and point of purchase material (merchandising) (Restrepo-Echavarría, 2017) }\end{array}$ \\
\hline & The use of emails - personalized emails for contacting voters. \\
\hline & The use of new resources: From SMS to WhatsApp (Restrepo-Echavarría, 2017) \\
\hline
\end{tabular}

Source: Work of the research team based on the quoted authors

Bearing all this in mind, the communicational dimension of the presidential campaigns in Colombia was structured based on three analysis categories: the discourse, the communicative process and the technical means (Table 2).

\subsection{Description of indices and frequencies}

Intensity represents the frequency of each of the indicators of professionalization in each of the presidential campaigns. In this way,

- when the indicator comes up frequently it will be classified with an intensity of two (2);

- if the frequency is average it will be classified with an intensity of one (1); and

-if the indicator reveals low or even zero frequency, the intensity rating will be zero (0).

Based on that, campaigns will be more professional providing the indicators of professionalization show a high frequency and, consequently a higher intensity score. For that end, we have established a protocol which defines the criteria which allow the level of intensity of each indicator to be assessed.

Finally, the Total Professionalization Index $\left(\right.$ INPROCO $\left.{ }_{T}\right)$ will be drawn up from the average intensity of professionalization of each dimension. The idea is to understand which dimension is the one which best explains the level of professionalization of presidential campaigns in Colombia. The average intensity of professionalization of each of the dimensions will be a value which oscillates between zero (0) and two (2) and the Formulae which allow the Total Professionalization Index $\left(I N P R O C O_{T}\right)$ to be calculated are:

Formula 1.

INPROCO $_{O}=\frac{\sum_{i=1}^{13} \text { Intensity of Organizational Dimension Indicators }}{i}$

Formula 2.

$\operatorname{INPROCO}_{C}=\frac{\sum_{i=1}^{14} \text { Intensity of Communicational Dimension Indicators }_{i}}{14}$

Formula 3.

$$
I N P R O C O_{T}=\frac{I N P R O C O_{O}+I N P R O C O_{C}}{2}
$$

Where:

$-I N P R O C O_{0}:$ Represents the average intensity of professionalization of the organizational dimension.

-INPROCO : Represents the average intensity of professionalization of the communicational dimension.

Table 3. Levels of professionalization of the electoral campaigns according to the INPROCO index

\begin{tabular}{|c|l|c|}
\hline $\begin{array}{c}\text { Professionalization index } \\
\text { (INPROCO) }\end{array}$ & $\begin{array}{c}\text { Level of } \\
\text { professionalization }\end{array}$ & $\%$ of professionalization \\
\hline $0 \leq I N P R O C O_{T}<0,5$ & Low & $0 \% \leq I N P R O C O_{T}<25 \%$ \\
\hline $0,5 \leq I N P R O C O_{T}<1$ & Medium & $25 \% \leq I N P R O C O_{T}<50 \%$ \\
\hline $1 \leq I N P R O C O_{T}<1,5$ & Medium -High & $50 \% \leq I N P R O C O_{T}<75 \%$ \\
\hline $1,5 \leq I N P R O C O_{T} \leq 2$ & High & $75 \% \leq I N P R O C O_{T} \leq 100 \%$ \\
\hline
\end{tabular}

Source: Work of the research team based on Neto (2007). 
The total professionalization index is a value which oscillates between zero (0) and two (2) and the levels of professionalization of the campaigns is set out in Table 3.

It is worth pointing out that this scale may also be used to analyze the levels of professionalization of the organizational and communicational dimensions (Restrepo-Echavarría, 2017).

\subsection{Intensity and frequency protocols of the indica- tors of Professionalization}

The intensity of each of the indicators which make up the organizational and communicational dimensions will be assessed for each case study based on the following criteria:

\subsubsection{Organizational dimension}

\section{Campaign management}

The score will be:

- zero: when the campaign management is de-centralized and has no expert participation;

- one: when it has centralized management, but no experts;

- two: when the management is centralized and has experts with no party link.

\section{Presence of external consultants in management areas}

The score will be:

- zero: when the campaign had no external consultant;

- one: when an external consultant participated occasionally during the campaign being in charge of specific functions, for example, the definition and carrying out of the campaign strategy;

- two: when the involvement of the external consultant was apparent during the whole campaign and they were in charge of defining and carrying out the political communication strategy.

\section{Funding}

The score will be:

- zero: if the campaign does not have an area specifically for fundraising and spending (Political Action Committees, or "PAC") or fundraising is the responsibility of the campaign manager or the candidate;

- one: if the campaign had a manager and a group in charge of money management (without a PAC), but fundraising was down to the candidate;

- two: if the campaign has a team of specialists specifically for fundraising and budgeting (PAC).

The use of social research to follow up on the perceptions and reactions of voters

The score will be:

- zero: if the campaign does not show signs of having either a group or project for internal research and building public agenda;

- one: if there is a management and systematization of public agenda issues, but no research group;

- two: if the campaign demonstrates extensive research by a support team of academic staff from the areas of economics, politics and sociology.

\section{Permanent campaign}

The score will be:

- zero: if, during the campaign, the candidate limits their communication strategy to the time period set by the electoral system;

- one: if the candidate seeks to generate communication strategies, both when they are competing for nomination and when they hold a public position, but the electoral system restricts the campaign period;

- two: when the candidate sets out a seamless continuum covering the electoral campaign and the communication and actions of the government in favor of a future campaign. Also, if there are no effective restrictions caused by the regulation of the electoral system.

\section{Professional campaign management}

The score will be:

- zero: when the campaign shows no signs of professional management;

- one: when the campaign is managed but there is no clear administrative role or when the campaign is managed by expert administrators who serve as militants collaborating with the party and the candidate;

- two: the campaign's score will be two when there is a tangible group of expert business management professionals who are paid for doing the job.

\section{Systematization of databanks}

The score will be:

- zero: if the campaign only uses basic Excel tables for organizing its lists of potential voters or has no database;

- one: if the campaign uses basic software for the systematization and gathering of data or it uses geo-referencing software without a clear strategy;

- two: if the campaign makes extensive use of geo-referencing tools, sophisticated data systematization software and boasts a team of experts who design the strategy based on data which guide the different campaign groups.

\section{The professionalization of the campaign team with a mul- ti- and inter-disciplinary team}

The score will be:

- zero: when the candidate and their helpers do all the work for the campaign;

- one: when some areas are managed by experts in the field and the rest is done by un-paid helpers;

- two: when it is made up of work areas and in each area there are expert professional staff who are paid for performing their functions in the campaign.

\section{Paid militancy in the campaign}

The score will be:

- zero: when all people involved are volunteers;

- one: when there is a combination of volunteers and paid staff in the campaign;

- two: when all staff are paid a salary for their work. 


\section{The campaign is personified in the candidate}

The score will be:

- zero: when the party and party leaders are the center of the campaign and not the candidate;

- one: when the focus of the campaign is on the candidate but they are reliant on the political party for developing the campaign strategy and the funding of the campaign;

- two: when the focus of the professionalization of the campaign revolves around the candidate and there is no sign of any influence of the party on the campaign strategy or the funding of the campaign.

Inter-party conventions, alliances and support or only the original party backing the campaign

The score will be:

- zero: when the candidate is chosen but there is no convention;

- one: if the party holds a convention to choose the candidate but does not have any inter-party alliances although, occasionally, some external support is received;

- two: is for when the candidate takes part in inter-party conventions and alliances and when they have a wide range of supporters giving them the profile of an "outsider".

Electoral monitoring, use of polls, surveys and focus groups

The score will be:

- zero: when the campaign uses neither surveys nor focus groups;

- one: when it interprets surveys and occasionally contracts opinion poll experts;

- two: when it has staff who are experts in the analysis of opinion polls, focus groups and surveys.

\section{Media training and group training}

The score will be:

- zero: when there is no evidence of training for the campaign team or the candidate tries empirically to organize their message and media strategy with the aid of helpers;

- one: when sporadic team training takes place, carried out by an external consultant, or the candidate attempts to prepare their political message or media appearances with the help of an external consultant;

- two: when both the team and the candidate have been trained by external advisers in the use of media and the construction of the message.

\subsubsection{Communicational dimension}

\section{Person-centered messages}

The score will be:

- zero: when there is evidence that the candidate's messages center on the party rather than "messianic" messages which focus on the candidate;

- one: if the messages mix the candidate and the party;

- two: the messages must have a high degree of focus on the candidate above the message of the party and ideology. As such, they allow an "outsider" candidate to be built up and promoted.

\section{The use of symbolic references}

The score will be:

- zero: when the content is direct and it is apparent that the sole interest is on informing;

- one: when the message seeks to build deep and emotional content;

- two: is for when the content of the message has a hidden, deeper sense which is present in the imagination of people. Those factors make propaganda messages more generally understood and precise in their meaning.

\section{Segmentation of messages}

The score will be:

- zero: when the campaign only contains standard messages, inviting people to vote for the candidate;

- one: when it distinguishes between publics but communicates the same message;

- two: when there is a high degree of fragmentation of messages, both between publics and as different types of messages, according to the target audience.

\section{The use of emotions in electoral messages}

The score will be:

- zero: when the content of the messages is direct and standard;

- one: will be for messages which generate emotion but do not tell a story;

- two: is for messages which have a high emotional level (fear, hope) and use stories, without the need for the candidate and political party - they simply suggest the candidate as an option.

\section{New types of political discourse}

The score will be:

- zero: when the traditional addresses are based on ideology and the party:

- one: when the addresses occasionally have some apolitical content but the basis is the party line and ideology;

- two: the messages must be designed using an apolitical speech, in the first person singular, typical of an outsider candidate.

\section{Support of opinion leaders}

The score will be:

- zero: when the campaign does not have the visible support of any leaders who generate opinion;

- one: when it has the support of a leading figure within the party or traditional politicians;

- two: is when the candidate has the support of high-profile personalities from outside the party who lead opinion, for example, business leaders, TV actors and actresses and/or important politicians from the country.

\section{Building the image and positioning the candidate}

The score will be:

- zero: when the candidate does not have a support team for advising them on their image, physical appearance and speech; 
- one: is for a campaign which, despite not having a team of professionals, does grant a lot of importance to the construction of physical appearance and speech;

- two: is for when the candidate has a team of professionals in charge of building his or her public image and designing the political discourse.

\section{Storytelling}

The score will be:

- zero: when the candidate has no speech strategy which includes traditional stories, and there is no previous preparation;

- one: when there are stories but they are unprepared and there is a lot of improvisation;

- two: when the candidate has a script prepared for the telling of stories both during speeches and when dealing with the media.

\section{Participation in televised debates and social forums}

The score will be:

- zero: if the candidate does not take part in debates and has no professional training for forums and debates;

- one: when the candidate takes part in debates and forums but has no previous professional training;

- two: when he or she takes part in all forums and debates, and has a high degree of professional training for speaking in public.

\section{The use of negative propaganda}

The score will be:

- zero: when the campaign shows no signs of a strategy of attacking rivals in the media;

- one: when the candidate draws up a strategic communication plan for attacking their rival but electoral rules do not allow such attacks;

- two: is for when attacks between candidates are systematic and constant both in public forums and in the media and throughout the publicity and propaganda strategy and, in addition, there is no prohibition from the electoral system.

\section{Advertising inserts in the mass media - public and private radio and television}

The score will be:

- zero: when there is no use of media advertising, either public or private;

- one: when there is some evidence of low-frequency use of paid media, but another, cheaper advertising strategy is favored;

- two: when there is a constant use of paid media as the main strategy in the campaign and, also, when the campaign shows high spending which aims the strategy at the media.

\section{The use of Internet}

The score will be:

- zero: if there is no use of Internet;

- one: if there is a basic use of text messages and free social networks, without a clear strategy of Internet use;
- two: when there is a constant use of the Internet throughout the political communication strategy - social networks, websites, multimedia, paid advertising on social websites, text messages and email.

The use of printed material for external use during electoral campaigns

The score will be:

- zero: when there is no use of printed material or it is merely incipient with only some flyers;

- one: when the campaign uses all kinds of printed material but not billboards because of their high cost;

- two: if it makes widespread use of billboards, outdoor advertising and mobile billboards, printed material and flyers, all contained within a signing strategy.

\section{The use of email and personalized mailing to contact voters}

The score will be:

- zero: when the campaign makes sporadic use of emails taken from the party's own database or there is no use of direct mailing and emails;

- one: when there is a frequent use of mass-mailing, such as with emails, but with no segmentation and using only the party's database and/or unsegmented direct mailing;

- two: when there is a high use of mass-mailing, for example, with emails, segmented mailing using professional databases in addition to the party's own database and segmented, direct mailing.

The use of new resources such as: sms, tele-marketing (with technical effects) and WhatsApp

The score will be:

- zero: when there is no use of these tools;

- one: when there is sporadic use and individual messages are sent using the tool but without any strategy or planning in the use of telecommunication tools;

- two: is for a campaign with a frequent use of telecommunication tools combined with a great strategy and planning. This would imply; telemarketing companies, databases and messages segmented according to specific publics. SMS would be used for adult publics and WhatsA$p p$ for young people

\section{Results}

With a view to analyzing and measuring the level of professionalization of the presidential campaign and showing the results of the INPROCO professionalization index, we chose as a case study the latest presidential campaigns of Juan Manuel Santos and Oscar Iván Zuluaga in Colombia in 2014. Following the methodology explained in the previous section, the indices of the organizational and communicational dimensions of each campaign were quantified.

The information needed for this analysis was obtained from the study of existing material, the media, and semi-structured interviews with campaign managers, advisers and consultants.

It should be remembered that Colombia is a country with an electoral tradition where there has not been a break-up 
Table 4. Measurement of the level of professionalization in the 2014 presidential campaign in Colombia - Organizational dimension

\begin{tabular}{|c|c|c|c|}
\hline Category & Indicator & Santos & Zuluaga \\
\hline \multirow{7}{*}{ Strategy } & Management of the campaigns: Centralized vs. De-centralized & 2.0 & 2.0 \\
\hline & Presence of external consultants in management areas & 2.0 & 2.0 \\
\hline & Management of funding - interest groups & 1.0 & 0.0 \\
\hline & Use of social research for following up the perceptions and reactions of voters & 2.0 & 2.0 \\
\hline & Permanent campaign. Breaking the strict, tight, timeframe of the campaign & 2.0 & 0.0 \\
\hline & Professional campaign management & 2.0 & 2.0 \\
\hline & Level of professionalization: Category - Strategy & 1.83 & 1.33 \\
\hline \multirow{6}{*}{ Tactics } & Systematization of databanks & 2.0 & 2.0 \\
\hline & Professionalization of the campaign team with a multi- and inter-disciplinary team & 2.0 & 2.0 \\
\hline & Paid militancy in the campaign & 2.0 & 2.0 \\
\hline & $\begin{array}{l}\text { Personification of the campaign in the candidate, moving away from the programs and ideologies of } \\
\text { the party }\end{array}$ & 2.0 & 1.0 \\
\hline & Inter-party conventions and alliances. Support & 1.0 & 1.0 \\
\hline & Level of professionalization: Category - Tactics & 1.80 & 1.60 \\
\hline \multirow{3}{*}{ Technique } & Electoral monitoring: use of polls, surveys and focus groups & 2.0 & 2.0 \\
\hline & Media Training and team training & 2.0 & 2.0 \\
\hline & Level of professionalization: Category - Techniques & 2.00 & 2.00 \\
\hline \multicolumn{2}{|c|}{ Level of professionalization: Organizational dimension $\left(\right.$ INPROCO $\left.{ }_{0}\right)$} & 1.85 & 1.54 \\
\hline
\end{tabular}

Source: Work of the research team based on the work of Restrepo-Echavarría (2017)

of the institutions as a consequence of totalitarian governments. Rather, there has been an uninterrupted sequence of elections since the beginning of the twentieth century.

Similarly, it is of particular interest to analyze this campaign since there were numerous indicators of professionalization, for instance; the use of new information technologies, the use of a negative propaganda campaign and the permanent campaign. It is also important to point out that this campaign was the re-election of Juan Manuel Santos opposed by the political group led by Alvaro Uribe and their candidate, Oscar Iván Zuluaga, who supported him in his first presidential election. The result of the analysis is the quantification of the professionalization index, based on the results obtained from this presidential campaign (Table 4).

In this campaign, both the candidate - President Juan Manuel Santos and the contender Oscar Iván Zuluaga had a high level of professionalization. In addition, it was found that the level of professionalization of the campaigns in this period was because of the communicational dimension rather than the organizational one. The average score for the level of professionalization of the communicational dimension is 1.86 whilst for the organizational dimension it is 1.69 . It is also worth pointing out that, for Santos' campaign, the score was the same for both dimensions.

\section{Conclusions}

When measuring the level of professionalization of the 2014 presidential campaign in Colombia it could be seen that the techniques of professionalization had evolved. This is apparent from the indices of the communicational dimension where communication techniques are an essential tool in presidential elections in the Colombian case. This case also reflects the way in which many electoral campaigns are being carried out in Latin America.

It is obvious that the strategic foundations of the country are adapting to the international dynamics where campaigns use the experiences and successful methods of campaigns on an international scale. These are then applied rigorously to the workings of national electioneering teams as is shown in the studies of Gibson \& Römmele (2001) and Crespo, Garrido \& Riorda (2008), where they explain how different ways of carrying out electoral campaigns have been developed through new technologies and mass media, in particular, television and the Internet.

On the other hand, this work on the index of professionalization of electoral campaigns not only invites us to extend communication and political marketing studies but it also sets the basis for any future analysis and research of issues such as: 
Table 5. Measurement of the level of professionalization of the communicational dimension in the 2014 campaign.

\begin{tabular}{|c|c|c|c|}
\hline Category & Indicator & Santos & Zuluaga \\
\hline \multirow{6}{*}{ Discourse } & Personalized messages & 2.0 & 2.0 \\
\hline & Use of symbolic references & 2.0 & 2.0 \\
\hline & Segmentation of messages & 2.0 & 2.0 \\
\hline & Emotional use of electoral messages & 2.0 & 2.0 \\
\hline & New types of political discourse & 0.0 & 0.0 \\
\hline & Level of professionalization: Category - discourse & 1.60 & 1.60 \\
\hline \multirow{5}{*}{$\begin{array}{l}\text { Communication } \\
\text { processes }\end{array}$} & Construction of image and positioning of the candidate & 2.0 & 2.0 \\
\hline & Storytelling & 2.0 & 2.0 \\
\hline & Participation in TV debates and social forums & 2.0 & 2.0 \\
\hline & Use of negative propaganda & 2.0 & 2.0 \\
\hline & Level of professionalization: Category - communication processes & 2.00 & 2.00 \\
\hline \multirow{6}{*}{ Technical media } & Advertising inserts in mass media: public and private radio and television & 2.0 & 2.0 \\
\hline & Use de Internet & 2.0 & 2.0 \\
\hline & $\begin{array}{l}\text { Use of printed material for external use during electoral campaigns: Non-party press, advertising mate- } \\
\text { rial, billboards, posters, flyers, point of purchase material (merchandising) }\end{array}$ & 2.0 & 2.0 \\
\hline & Use of email and personalized mailing to contact voters & 2.0 & 2.0 \\
\hline & Use of new resources: from sms to WhatsApp & 2.0 & 2.0 \\
\hline & Level of professionalization: Category - technical means & 2.00 & 2.00 \\
\hline \multicolumn{2}{|c|}{ Level of professionalization: Communicational dimension $\left(\right.$ INPROCO $\left.{ }_{c}\right)$} & 1.86 & 1.86 \\
\hline
\end{tabular}

Source: Work of the research team based on Restrepo-Echavarría (2017)

- comparative analyses of professionalization in countries with a similar profile;

- studies of the impact of professional techniques on the voting decisions of the electorate;

- focusing on the person in politics and its impact on electoral volatility and party institutions;

- analyses of the effects of the media on electoral campaigns; and

- studies on how professionalization affects democracy.

Given that, in terms of methodology, this research transcends qualitative analysis and incorporates the measurement of levels of professionalization in electoral campaigns into person-centered political systems, it also makes it possible to carry out comparative studies with other countries whose democratic system is similar to the Colombian one and where globalization, in all its manifestations, has a homogeneous impact on political activity.

Similarly, the measurement of the level of professionalization goes beyond descriptive studies of electoral results and the effects of elections, to bring in the concept of dimensions which can be explained by means of categories. These categories, in turn, are grouped as indicators which are inherent to modern politics with the boom in the focus on the person in politics.

\section{References}

Beccassino, Ángel (2008). La nueva política. El entorno y la comunicación electoral. Argentina: Grijalbo. ISBN: 978958 6395939

Blumler, Jay (1999). "Tendencias de la comunicación política en las campañas electorales británicas". En: Muñoz-Alonso, Alejandro; Rospir, Juan-Ignacio (eds.). Democracia mediática y campañas electorales. Madrid: Ariel, pp. 111-124. ISBN: 9788434412774

Castells, Manuel (2009). Comunicación y poder. Madrid: Alianza Editorial. ISBN: 9788420684994 https://goo.gl/5ZnMYQ

Crespo, Ismael; Garrido, Antonio; Riorda, Mario (2008). La conquista del poder. Elecciones y campañas presidenciales en América Latina. Buenos Aires: La Crujía. ISBN: 9789876010641

Cotarelo, Ramón (2010). La política en la era de internet. Valencia: Tirant lo Blanch. ISBN: 9788498769425

Farrel, David (1996). "Campaign strategies and tactics". En: Le-Duc, Lawrence; Niemi, Richard; Norris, Pippa (eds.). Comparing democracies: Elections and voting in global perspective. SAGE Publications, pp. 160-183. ISBN: 9780 803958364 
Freidenberg, Flavia (2010). Campañas electorales y democracia. Salamanca: Documento en elaboración. Universidad de Salamanca.

flavia@unam.mx

Gibson, Racher; Römmele, Andrea (2001). "Changing campaing communication. A party-centered theory of professionalized campaigning". The Harvard international journal of press / politics, v. 6, n. 4, pp. 31-43.

https://goo.gl/cwjjF7

https://doi.org/10.1177/108118001129172323

Gibson, Racher; Römmele, Andrea (2009). “Measuring the professionalization of political campaigning". Party politics, v. 15, n. 3, pp. 265-293.

https://www.dcern.org.uk/wp-content/uploads/2017/07/ GibsonRommeleCampaigns.pdf

https://doi.org/10.1177/1354068809102245

Holtz-Bacha, Christina (2002). "Campañas electorales en Alemania". En: Priess, Frank. Relación entre política y medios. Propuestas alemanas en una perspectiva comparada. Buenos Aires: Fundación Konrad Adenauer, pp. 207-229.

Izurieta, Roberto; Arteton, Christopher; Perina, Rubén (2003). Estrategias de comunicación para gobiernos. Buenos Aires: La Crujia. ISBN: 9789871004140

Kavanagh, Dennis (2004). "Democracia partidaria y marketing político: ¿Sin lugar para aficionados?”. Diálogo político, v. 21, n. 1 , pp. 33-45.

http://www.kas.de/argentinien/es/publications/5227

Maarek, Philippe (2009). Marketing político y comunicación. Claves para una buena información política (2- ed.). Barcelona: Paidós Ibérica. ISBN: 9788449322617

Mancini, Paolo (1995). “Americanización y modernización. Breve historia de la campaña electoral". En: Muñoz-Alonso, Alejandro; Rospir, Juan-Ignacio (eds.). Comunicación política. Madrid: Editorial Universitas, pp. 141-168. ISBN: 97884 79910396

Martínez-Pandiani, Gustavo (2006). "El impacto de la televisión en la comunicación política moderna”. Revista signos universitarios, v. 25, n. 1, pp. 67-88.

http://p3.usal.edu.ar/index.php/signos/article/view/2955

Mazzoleni, Gianpietro (2010). La comunicación política. Madrid: Alianza Editorial. ISBN: 8420669407

Mintzberg, Henry (1979). "An emerging strategy for 'direct' research". Administrative science quarterly, v. 24, n. 4, pp. 582-589.

https://doi.org/10.2307/2392364
Múnera-Uribe, Pablo-Antonio; Sánchez-Zuloaga, Uriel-Hernando (2003). Comunicación empresarial. Una mirada corporativa. Medellín: AICE. ISBN: 9789583356780

Neto, Fenelon-Martins-da-Rocha (2007). La profesionalización de las campañas electorales en Brasil (1989-2006). Salamanca: Universidad de Salamanca. https://gredos.usal.es/jspui/handle/10366/18601

Norris, Pippa (2001). “¿Un círculo virtuoso? El impacto de las comunicaciones políticas en las democracias post-industriales". Revista española de ciencia política, n. 4, pp. 7-33. https://recyt.fecyt.es/index.php/recp/article/view/37313

Norris, Pippa (2004). "The evolution of election campaigns: Eroding political engagement?". En: Political communication in the $21^{\text {st }}$ century. St Margaret's College, University of Otago, New Zealand. https://goo.gl/AkESQx

Orejuela, Sandra (2006). "Proceso de globalización a la profesionalización". Revista de comunicación, v. 5, pp. 55-87. http://revistadecomunicacion.com/pdf/2006/Art055-087.pdf

Plasser, Fritz; Plasser, Gunda (2002). La campaña global: Los nuevos gurúes del marketing político en acción. Buenos Aires: Temas. ISBN: 9789879164679

Ramos-Meneghetti, Marisa (2003). Americanización de las campañas electorales: Elecciones presidenciales Argentinas de 1999. Tesina. Madrid: Universidad Complutense de Madrid.

Restrepo-Echavarría, Néstor-Julián (2015). "La profesionalización de las campañas electorales: las elecciones presidenciales de Colombia 2010". Revista española de ciencia política, n. 38 , pp. 85-114.

https://recyt.fecyt.es/index.php/recp/article/viewFile/37664/21181

Restrepo-Echavarría, Néstor-Julián (2017). La profesionalización de las campañas electorales en Colombia: las elecciones presidenciales en Colombia 1994-2014. Tesis doctoral. Universidad Complutense de Madrid.

https://www.ucm.es/data/cont/docs/1208-2017-07-12Tesis_Julian_Restrepo.pdf

Rospir, Juan-Ignacio (1999). "La globalización de las campañas electorales". En: Muñoz-Alonso, Alejandro; Rospir, Juan-Ignacio (eds.). Democracia mediática y campañas electorales. Madrid: Ariel, pp. 55-88. ISBN: 9788434412774

Swanson, David; Mancini, Paolo (1996). Politics, media and modern democracy: An international study of innovations in electoral campaigning and their consequences. ISBN: 9780 275951832 